\title{
«En un viaje de placer» \\ Representaciones de la temporalidad a través de postales, folletos y fotos sobre Panamá y Cuba durante la primera mitad del siglo $\mathrm{XX}^{1}$
}

\author{
"On a pleasure trip" \\ Representations of temporality through postcards, brochures \\ and photos about Panama and Cuba during the first half of the \\ $2 O^{\text {th }}$ Century \\ Inés Yujnovsky \\ Universidad Nacional de San Martín \\ Argentina
}

DOI: https://doi.org/10.25032/crh.v7i12.8

Recibido: $30 / 3 / 2021$

Aceptado: 23/5/2021

Resumen. A principios del siglo xx la circulación de piezas gráficas efímeras como postales, folletos, menús, tickets y álbumes fotográficos se amplió junto a la expansión de los viajes gracias al desarrollo de nuevos medios de transporte como los barcos a vapor que ofrecieron mayores comodidades, más velocidad y previsión. La iconografía relacionada con dos puntos centrales de interés turístico, como las ciudades de Panamá y de Cuba pone de manifiesto imaginarios espaciotemporales respecto de Caribe y América Latina. Este trabajo analiza las representaciones de la temporalidad en la definición de esos imaginarios. Las ruinas, el pasado hispánico colonial, la presentación binaria pasado-presente fueron tópicos reiterados para promover aventura y romance en los viajes de placer, pero que también generaron una distancia espacio temporal que ubicaba en una condición de lejanía y subordinación a los países latinoamericanos.

Palabras clave: fotografía, temporalidad, viajes, siglo xx

\footnotetext{
${ }^{1}$ Este trabajo ha sido realizado gracias a la beca de Investigación Richard E. Greenleaf de la Biblioteca Latinoamericana de la Universidad de Tulane, Nueva Orleans. Quiero agradecer a Hortensia Calvo, Christine Hernández y Verónica Sánchez por la gran cordialidad con que me recibieron y la excelente labor que desarrollan.
} 
Abstract: At the beginning of the 2oth century, the circulation of ephemeral graphic pieces such as postcards, brochures, menus, tickets together with photographic albums expanded along with the expansion of travel thanks to new technology such as steamships that offered greater comforts, more speed and foresight. The iconography related to two central points of tourist interest of the cities of Panama and Cuba, reveals imageries of the Caribbean and Latin America. This work analyzes the representations of temporality in the definition of these imaginaries. The ruins, the colonial Hispanic past, the pastpresent binary presentation were reiterated topics to promote adventure and romance in pleasure trips. These visions generated a spatio-temporal distance that placed the Latin American countries in a condition of remoteness and subordination.

Keywords: photography, temporality, travel, 2oth century

\section{De folletos, postales y álbumes}

Temporal differences matter!

(Moxey 3)

Las perspectivas de historia global han puesto en evidencia la necesidad de observar la circulación, las historias conectadas y una ampliación de los marcos temporales en contraste con las historias nacionales que al centrarse en países aislados oscurecieron las vinculaciones y pueden incurrir en el riesgo de resaltar como particularidades visiones más generalizadas. La importancia de la circulación es un hecho indiscutible en la cultura visual durante el cambio del siglo XIX al XX. Para comprender la densidad de las conexiones en este ámbito no alcanza con analizar la producción de piezas gráficas y es también necesario atender a los usos y modos de apropiación. Los estudios sobre el consumo se han ampliado en las últimas décadas, dejando de lado prejuicios acerca de la pasividad de los consumidores. Como sostiene Natalia Milanesio, hay que considerar «el rol del consumo como una arena de creación de representaciones y de construcción del sujeto» (199).

En consonancia con representaciones tradicionales, regiones como Panamá o Cuba eran vistas con una predominancia de la naturaleza que se complementaba con la llegada incipiente de la modernidad. Marixa Lasso puso en evidencia el acto de vaciamiento de la 
zona del Canal generando la idea de sociedades nativas naturales. Sostiene que en 1912 ese espacio era una de las áreas más pobladas de Panamá. Sin embargo,

al contrario de las narrativas tradicionales, la despoblación de los pueblos panameños en la zona del canal no fue un efecto secundario de la construcción del canal, sino que involucra la decisión muy diferente de expulsar a los habitantes de toda la zona del canal. Una retórica que enfatizaba la conexión de los panameños negros con una naturaleza tropical atemporal ayudó a silenciar la modernidad económica y tecnológica de las personas que vivían y trabajaban en una región que había estado a la vanguardia de la tecnología del transporte desde el siglo XVI (Lasso a 241).

En las primeras décadas del siglo Xx se consolidó la celebración de la modernidad. La expansión económica, el crecimiento de los ferrocarriles y de obras de infraestructura fueron pilares para visibilizar las ideas de progreso sostenidas sobre la tecnologización, la racionalización y una historia como totalidad que tendiera a mejoras universales. La construcción del Canal de Panamá fue uno de los paradigmas visuales de los avances tecnológicos. Numerosas piezas gráficas mostraron la construcción, las gigantescas compuertas de hierro, la represa, la energía, el sistema de iluminación, la monumentalidad y los barcos atravesando el río (Reese y Reese). Sin embargo, esas visiones de modernidad se complementaron con representaciones del pasado. La construcción temporal tuvo estrecha relación con los imaginarios sobre los países del Caribe, de América Latina en general y de su lugar subordinado en el concierto de las naciones.

Como sostiene el antropólogo holandés Johannes Fabian, la práctica de conocimiento «bendijo un proceso ideológico mediante el cual las relaciones entre Occidente y su Otro, entre la antropología y su objeto, no solo fueron concebidas como diferencia, sino como distancia en espacio y tiempo» (198). Fabian explica que las relaciones se dieron a través de la negación de la coetaneidad, es decir una «tendencia persistente y sistemática a colocar el(los) referente(s) de la antropología en un tiempo distinto al presente del productor del discurso antropológico» (56). Esa negación de la coetaneidad es para Fabian «un acto político, no solo un hecho discursivo. La ausencia del Otro de nuestro tiempo ha sido su modo de presencia en nuestro discurso - como objeto y víctima-» (207). La distancia temporal tuvo, para este autor, «dispositivos de distanciamiento temporal» de carácter visual y que «la hegemonía de lo visual-espacial tuvo su precio: en primer lugar, destemporalizar el proceso del conocimiento y, en segundo lugar, promover la temporalización ideológica de las relaciones entre el conocedor y lo conocido» (215). 
Siguiendo las propuestas de Fabian, el historiador del arte Keith Moxey sostiene que:

la diferencia temporal importa tanto como otras formas de diferencia ampliamente discutidas y adoptadas como ejemplos de interpretación histórica en el pasado reciente. Si la clase, la etnia y el género se consideran aspectos significativos de las narrativas históricas, entonces también deben tenerse en cuenta las afirmaciones de la heterocronía en que el tiempo está marcado por características culturales distintas (3).

En consecuencia, destaca la importancia de considerar la coexistencia de diversas formas del tiempo global (Moxey 6). A partir de allí sostiene que la historia del arte ha insistido demasiado en entender la obra de arte en su momento de creación dejando de lado los diversos tiempos de su interpretación.

Con estos marcos de referencia, este trabajo analiza las representaciones de la temporalidad que circularon en las imágenes turísticas de las ciudades de Panamá y La Habana en las primeras décadas del siglo Xx. Los aspectos más difundidos estuvieron vinculados con las imágenes de ruinas, el pasado hispánico colonial, la relación binaria pasado/presente y la fugacidad (como un tiempo propio de los viajes de placer), entre otras. La hipótesis es que esas representaciones colaboraron en la generación de una visión de diferencia espacio temporal que negaba coetaneidad a estos países y que, por lo tanto, ubicaba en una condición de lejanía y subordinación a las naciones latinoamericanas.

El análisis se hace a través de objetos visuales tales como postales, folletos, menús, tickets que en los archivos se resguardan con el nombre de materiales efímeros elaborados por compañías de barcos, así como empresas turísticas comerciales y estatales en las primeras décadas del siglo Xx. Se trata de pequeñas piezas gráficas que tienen una gran posibilidad de ser desechadas, pero que los viajeros y viajeras guardaban como recuerdos atesorados de sus recorridos. Los archivos utilizan un término temporal para referir a materiales que han sido considerados menores, anónimos, que no tienen estatuto como obras de arte, mapas, libros o incluso fotografías. Se les da un tratamiento especial, quedando como objetos sueltos, que al tener diversos formatos y tamaños se solían separar del resto de los documentos en los que figuraba la información de los productores, coleccionistas o consumidores que habían guardado sus archivos personales, de modo que a veces se ha perdido información valiosa. 
La expansión de la cultura visual estuvo entrelazada con el aumento de los viajes, la mayor velocidad y estabilidad de los transportes y la búsqueda por recorrer y acercar las distintas regiones del mundo. Dos prácticas de la vida privada fueron decisivas para el desarrollo de la postal como dispositivo visual de intercambio masivo: la tradición de la escritura epistolar y el coleccionismo. En la década de 1870 la unificación mundial del sistema de correos puso orden en la circulación de la correspondencia que en un mundo en expansión había casi colapsado. Asimismo, la escritura de un texto breve contribuyó al aumento e inmediatez del caudal epistolar (Masotta 69). Las imágenes que ofrecían pequeños recortes de mundos extraños le dieron una potencia extraordinaria a una nueva forma de comunicación de dimensiones mundiales.

La investigación se llevó adelante en la Biblioteca Latinoamericana de la Universidad de Tulane, en Nueva Orleans, donde se han podido relevar materiales de diversos países, en especial de la zona del Caribe en la que se inscribe también esta región del sur de Estados Unidos. Poner el foco en esta región permite observar la circulación durante este período. Se han seleccionado los casos de Panamá y Cuba porque fueron puntos destacados de circulación en este período. Gran cantidad de viajeros y viajeras visitaban ambos países. El trabajo no pretende hacer una historia comparada de los países, aunque sí una mirada de conjunto para observar si cada caso fue único o formaban parte de estereotipos más amplios de la época. Interesa pensar los casos de Cuba y Panamá como parte de circuitos más amplios que se divulgaban en la publicidad y que estimulaban representaciones específicas. En este sentido Claudia Troncoso ha estudiado las propuestas de recorridos turísticos en la ciudad de Salta (Argentina), mostrando el énfasis de recorridos a pie en el centro histórico, la organización que prevé visitas de dos o tres días y las representaciones que ofrecen un lugar de importancia al período colonial. Asimismo, presta atención a las formas en que estos destinos están atravesados por el movimiento de los propios turistas (Troncoso).

\section{Panamá La Vieja}

Panamá La Vieja o Panamá Viejo es el nombre que se le da al área central del primer emplazamiento de la ciudad, ubicada allí entre 1519 y 1671. En el siglo XX se convirtió en un punto de interés turístico y como tal fue retratado en fotografías y reproducido en postales. Una de esas imágenes, realizada cerca de 1910, muestra una torre de unos cuatro pisos de altura que emerge entre la vegetación tropical (Fig. 1). 


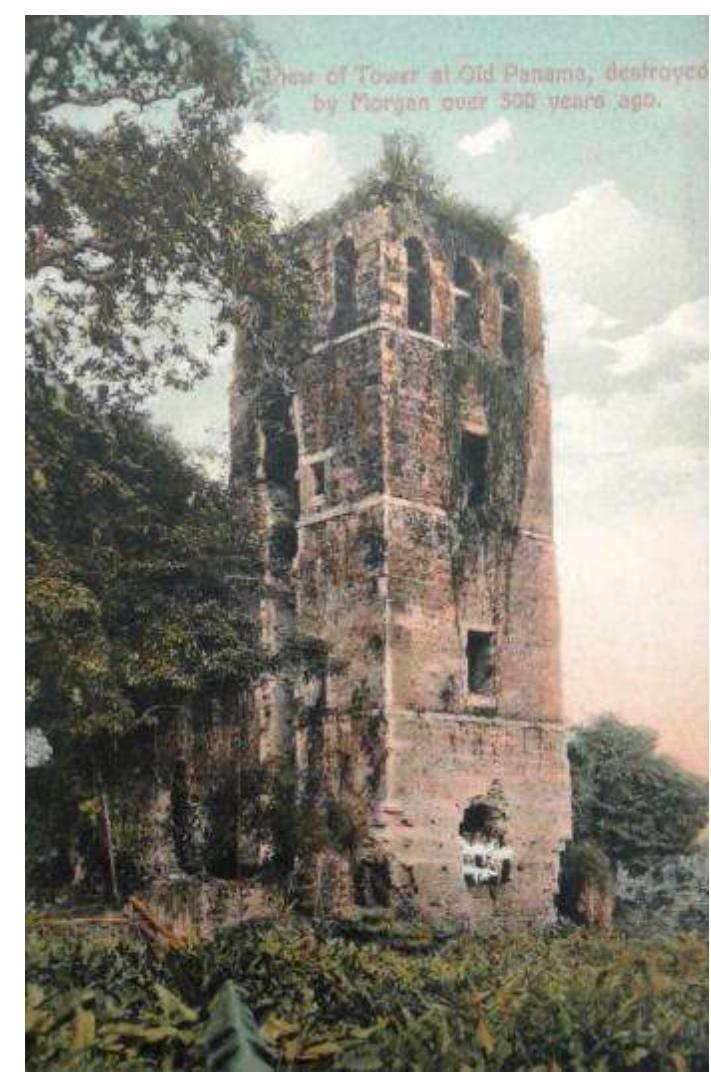

Fig. 1. Postal: «View of Tower at Old Panama destroyed by Morgan over 300 years ago». Image Archive, The Latin American Library, Tulane University.
No solo la rodean árboles altos y plantaciones de bananos, sino que además de los huecos que habían sido las ventanas caen enredaderas de varios metros de longitud y en lo alto, sobre la terraza, un techo verde de múltiples ramas sobresale de la antigua fortaleza. Se trata de una postal coloreada de principios de siglo XX, atesorada por turistas que viajaban a Panamá como recuerdo de la visita y que enviaban a familiares y amigos. El epígrafe, que está en inglés, dice «Vista de la torre en Panamá Viejo destruida por Morgan hace más de 300 años». ${ }^{2}$ La imagen muestra los efectos de la erosión sobre la piedra y el ladrillo, así como el avance de la selva sobre las construcciones y el texto destaca un hecho histórico sucedido hace varios siglos que quedó en la memoria colectiva por su aura mítica, de aventura, piratas y luchas entre ingleses y españoles. Se busca transmitir el paso de un gran lapso temporal que provoque sentimientos de una profunda historia antigua. Los efectos del clima y la vegetación generando destrucción y abandono muestran el fin de una cultura, que puede haber sido gloriosa, pero que ya no tiene efectos concretos sobre el presente.

${ }^{2}$ Los textos que en el original están en inglés han sido traducidos por la autora. 
Otra postal de la torre (Fig. 2), realizada en las primeras décadas del siglo XX,

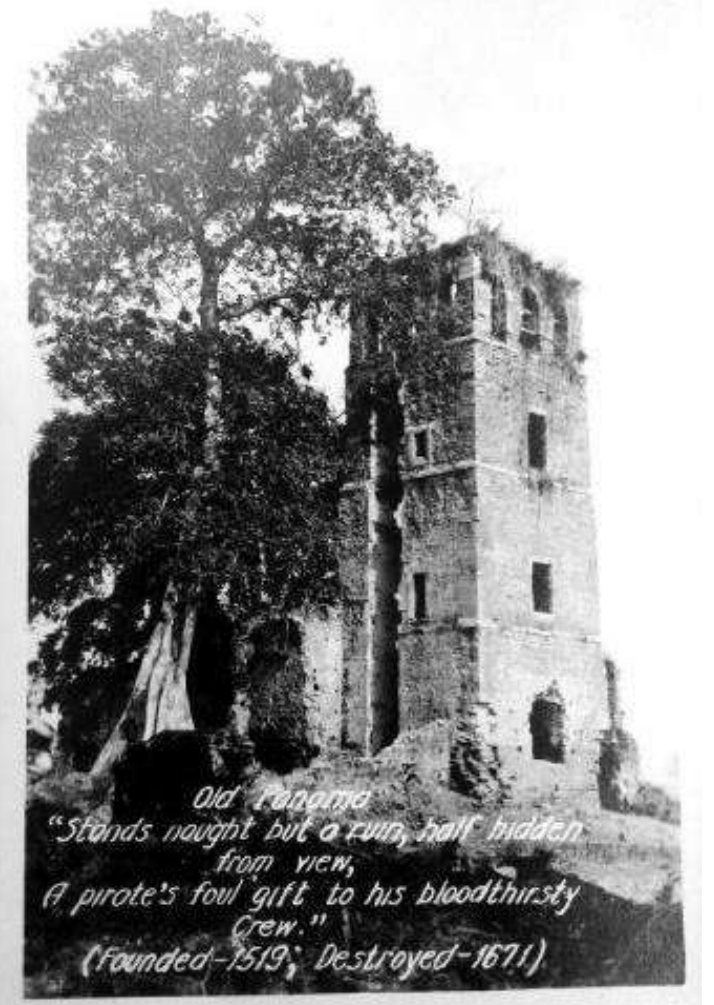
incluye un epígrafe estereotipado: «La Vieja Panamá no se encuentra más que en ruinas, medio escondida a la vista, el horroroso regalo de un pirata a su sanguinaria tripulación: (Fundada en 1519, Destruida en 1671)». El texto busca explicar los motivos por los que la torre está en ruinas. Antigüedad, ruina, vista, sangre y piratas son los términos para referirse de un modo efectista a ese pasado. La imagen muestra el paso irreversible del tiempo, pero el texto no solo especifica las fechas exactas, sino que agrega culpables. Esta pieza gráfica ofrece una idea de ruptura: una vieja Panamá que de manera implícita se opone al presente moderno. Pareciera incluso que se quiere apelar a la ausencia de temporalidad: en vez de un pasado que fue generando cambios es la naturaleza la que va modificando muy lentamente la construcción. Una vasta literatura ha mostrado que la idea de ruinas es una invención de la modernidad en su esfuerzo por mostrar un rompimiento con el pasado.3 A fines del siglo XVIII las ideas estéticas del romanticismo aludían a las ruinas como forma de decadencia de un imperio, una era de esplendor pasada que, debido a alguna catástrofe o incapacidad humana, había generado el declive irrevocable. En 1911, el sociólogo alemán Georg Simmel describió la visión de una ruina como un acomodamiento entre el ambiente y el espíritu humano, el objeto artificial deslizándose hacia un estado orgánico en que la naturaleza comienza a tener la ventaja (379). Para Simmel las ruinas muestran la transformación natural de lo humano, de su cultura material (Graves-Brown et al.). Los vestigios producen un efecto de melancolía de un pasado mejor, pero también aluden al deseo de imponer una nueva civilización sobre una grandeza antigua. Por otra parte, se trataba de una experiencia del pasado: ver, sentir y emocionarse ante el esplendor antiguo y el proceso de desaparición.

3 Un resumen de algunas posturas sobre las ruinas en tanto construcción simbólica puede verse en Gordillo, 2014, p. 8. Otro libro muy interesante que resume representaciones de las ruinas a lo largo del tiempo es Makarius, 2004. 
En la imagen de la torre hay un grupo de personas, no se los distingue con detalles ya que se ven pequeños en la inmensidad natural, pero podrían ser turistas o un grupo de estudiantes asomados en uno de los huecos de una antigua ventana. Así la postal subraya la presencia humana en un espectáculo salvaje que muestra e impulsa la posibilidad de acceder y experimentar las sensaciones que se producen al recorrerlas. El interés por las ruinas tenía un componente emocional y afectivo que alentaba a los viajeros a buscar este tipo de vestigios. Al contrastar diversas postales de la torre unos años después, a medida que nos acercamos a la mitad del siglo Xx, se observa un proceso de arqueologización de este espacio. La naturaleza que producía una parte central del efecto del paso del tiempo, la melancolía y la contemplación sublime da lugar a una rasuración: se corta el pasto, se quitan las malezas que sobresalen de la parte superior y se podan los árboles. De ese modo las imágenes pierden parte del efecto sublime para acercarse a un modo más documental en el sentido de ofrecer cierta objetividad y generar efecto racional más que emocional. En vez de una visión de la torre aislada se muestra una perspectiva panorámica en la que se ven otros restos fragmentados junto a la torre central. Gastón Gordillo prefiere utilizar la palabra escombros para evitar los significados románticos de las ruinas y retoma la distinción entre los dos conceptos. Lo que destaca la ruina-como-abstracción es el pasado del objeto. El pasado se cristaliza en los esfuerzos por presentar las ruinas como objetos separados del presente (8). En cambio, la idea de escombro refiere a un objeto que carece de forma y tiene una negatividad no codificada. De ahí que se genera una jerarquía en la que los escombros se ven como algo menor. Por ello, en los procesos de restauración de restos arqueológicos se trata de dar estatus de ruina a los escombros (10). Como sucede en estas fotografías, de la década de 1920 en adelante, se ha ampliado la noción de ruina al conjunto arqueológico mediante la inclusión de lo que antes se concebía como piezas sueltas que no eran dignas de atención emocional.

En otra imagen de ese período se incluye un automóvil junto a las ruinas (Fig. 3), el epígrafe menciona que son los restos de la Misión Española en alusión a lo poco que quedaría del mundo hispano-católico y el contraste con un símbolo de la modernidad. Al mismo tiempo se muestra un cómodo acceso ya que en vez de selva se ve un camino por el que pueden circular los autos y los turistas. Como sostiene Gordillo, quien a su vez retoma a Ann Stoler, es necesario desviar nuestra mirada de las ruinas hacia los procesos de ruinificación. De este modo se destacan las fuerzas activas de destrucción que crean los palimpsestos de «escombros imperiales» (11). La serie de imágenes de la Torre de Panamá muestra ese proceso de construcción cultural de la ruina cuya interpretación se 
va modificando con el paso del tiempo. Como sostiene Gordillo, retomando esta vez a Martin Heidegger, la cualidad definitoria de este tipo de lugares es que reúnen, atraen gente, recuerdos y efectos a su alrededor. Esto significa que los lugares son nodos más que contenedores: puntos hacia los que convergen relaciones y líneas de movimiento y desde donde se mueven para enredar otros nodos (21).

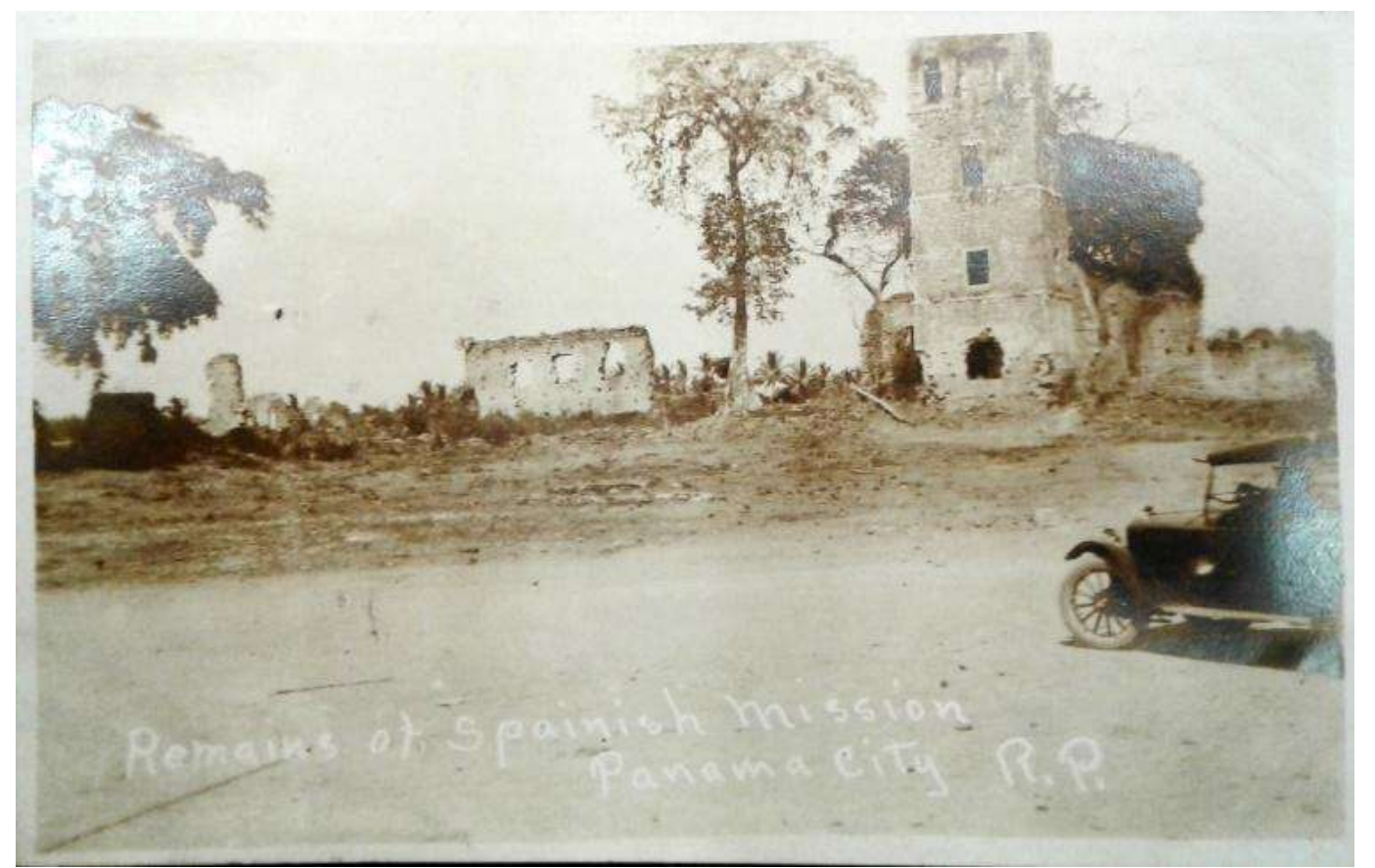

Fig. 3. Foto «Remains of Spanish Mission, Panamá City R. P.». Image Archive, The Latin American Library. Tulane University.

En estos años se estaba construyendo una de las obras más importantes de ingeniería mundial como fue el Canal de Panamá. Miles de postales retrataron la construcción, las compuertas, los barcos, el ferrocarril para hacer gala de la modernidad, pero esta serie de postales de la Torre de la Vieja Panamá muestra una representación temporal que pone de manifiesto la exhibición de un lejano pasado colonial que se va modificando: las primeras enfatizan la naturaleza sublime que se impone a las ruinas para ir dando lugar a un espacio más despojado, de fácil acceso para una visita rápida e instructiva.

\section{El viaje de Edith Bayne Aiken Denegre a Panamá: experimentar el pasado}

Ante estas imágenes prototípicas el relato y un álbum que compuso una mujer norteamericana en su viaje a Panamá permite observar el impacto de la percepción del pasado en la experiencia personal. El álbum contiene una selección de postales y piezas gráficas de los sitios que visitó la viajera, no hay fotos que tomó ella, su trabajo es el de 
edición, apropiación y colección selectiva, que pone en evidencia su consumo visual. Junto a este material se acompaña un relato al estilo diario de viaje que permite comprender el alcance de ese recorrido discursivo.

Edith Bayne Ayken Denegre nació en 1863, en el seno de una familia acomodada de Luisiana. Su padre fue uno de los abogados más prestigiosos de Nueva Orleans y su abuelo John Gayle fue gobernador de Alabama, entre 1831 y 1835. Tuvo una vida activa: viajó, escribió, estudió y trabajó como voluntaria. Participó de numerosas instituciones en las que colaboró a favor de niños, niñas y mujeres necesitadas. Se casó con el abogado George Denegre, no tuvo hijos, pero la hermana de Edith, Amelia Elizabeth, Minna, falleció a los 25 años en 1893 por lo que Edith y su esposo se ocuparon de sus sobrinos. Por veinte años colaboró con la Sociedad de Ayuda a los viajeros de Nueva Orleans (Traveler's Aid Society) que buscaba proteger en especial a mujeres y niñas que viajaban solas y podían caer en manos de la trata de personas. Junto a su esposo tuvieron una casa de veraneo y además colaboró con el asilo para niños St. Vincent. Fue clase 1906 del Newcomb College de la Universidad de Tulane en Nueva Orleans, es decir que estudió cuando ya tenía cuarenta años. Fue miembro del Círculo Francés del Newcomb. En el anuario Jambalaya de 1904 (147) aparece como integrante de Luisiana Alpha, la sección regional de Pi Beta Phi, una fraternidad internacional y secreta de mujeres fundada en 1867 para la cooperación y la ayuda femenina. Las miembros se involucraban en programas filantrópicos, en este caso enfocadas hacia educación, literatura, artes y manualidades. Entre 1904 y 1911 realizó viajes a la Feria de St. Louis, a Europa, Cuba y Panamá. También escribió una breve historia de México desde la época de los Toltecas a Madero. Murió en 1936 a los 73 años.

En 1911 Edith Bayne parte de Nueva Orleans a Panamá. En la primera página del álbum Edith colocó la lista de pasajeros en la que se destaca la gráfica atractiva del banderín, una pieza acorde para dar inicio al relato visual del viaje con el nombre del barco, del capitán, la fecha de partida y el destino. Esto permite saber que viajó en el S. S. Abangarez que partió el 21 de enero de 1911 al mando del capitán S. Barbrick. Este buque era uno de los trece transportadores bananeros de cinco mil toneladas brutas -aunque también llevaban pasajeros - construidos entre 1908 y 1911 para la United Fruit Company, la gran empresa multinacional dedicada a la producción y comercialización de frutos tropicales en Centroamérica. Aunque Bayne no incluyó el interior del folleto con los nombres de los pasajeros en su relato expresa que a bordo había gran cantidad de 
personas que parecían todas similares hasta que revelaron su destino, cada uno tenía motivos diferentes y se dirigían a países como Colombia, Perú o Venezuela, entre otros. Luego Edith colocó en el álbum el itinerario impreso que muestra la partida de Nueva Orleans el sábado a la mañana, teniendo que cumplir un aislamiento hasta la tarde, pasando por Cuba el lunes, Belice, la isla del Cisne y Nicaragua el martes, Costa Rica el miércoles, llegando a Panamá el jueves 26, cinco días después de la partida. Al inicio del álbum también pegó dos fotos comerciales del barco, una vista general en alta mar y otra con hombres y mujeres descansando y jugando en la cubierta. En otra página hay más fotos recortadas de un folleto comercial realizado por la línea marítima que muestran las comodidades de los camarotes de lujo y los distintos salones de estar, juego, etc. De ese modo Edith exhibe las novedades que alentaron la expansión de este tipo de viajes a principios del siglo Xx. Ya no se trata de una aventura arriesgada y peligrosa, sino prevalece el placer tanto para hombres como para mujeres y niños.

Cuando llega a la ciudad de Colón, en Panamá, la recibe su pariente William Crawford Gorgas y atraviesan el istmo en automóvil y tren. El colonel Gorgas, como lo llamaba Edith, fue un reconocido médico cirujano general de la Armada de Estados Unidos que impulsó el control de mosquitos transmisores que causaban enfermedades tropicales. Había trabajado en Cuba y cuando Edith lo visita era el jefe de sanidad durante la construcción del Canal. Es decir que la Sra. Bayne fue a la casa de un personaje bien posicionado que ofrece buena información y seguridad.

La capital de Panamá no le da buena impresión, dice que las casas y hospitales parecen pajareras. Algunas de las imágenes del álbum dan esa sensación: las edificaciones muestran filas de ventana, como si fueran pequeñas habitaciones una al lado de la otra. En contraste a esas escenas comenta que

Una vez dentro de la casa, la escena cambió a una tierra de hadas. El porche del té era una masa de plantas gloriosas y brillantes, en los postes había orquídeas; del techo colgaban cestas exuberantes; sillas cómodas esparcidas alrededor; y pequeñas mesas de té, con plata hecha a mano de la tierra de los Incas, iprobablemente usada por ellos! Lo mejor de todo fue la vista del brillante Océano Pacífico casi tan azul como el cielo y adornado con pequeñas islas (Bayne $5-6)$.

Al final del álbum hay cuatro fotografías del porche, el living y el comedor que muestran la descripción de Edith. En dos de las fotos hay una mujer sentada leyendo, pero no hay seguridad que sea ella, podría ser que le hayan regalado las fotos y los retratos sean de alguien más de la familia. Sea un retrato de Edith o no, muestran el confort de la casa, de espacios femeninos, para leer, tocar el piano, tomar el té, con espejos, fotografías, un área 
de reposo y sociabilidad para las familias y sus invitados en el que se destaca la belleza de la luz que entra por las ventanas con las plantas que ella describe en este párrafo de encuentro y asombro (Fig. 4).

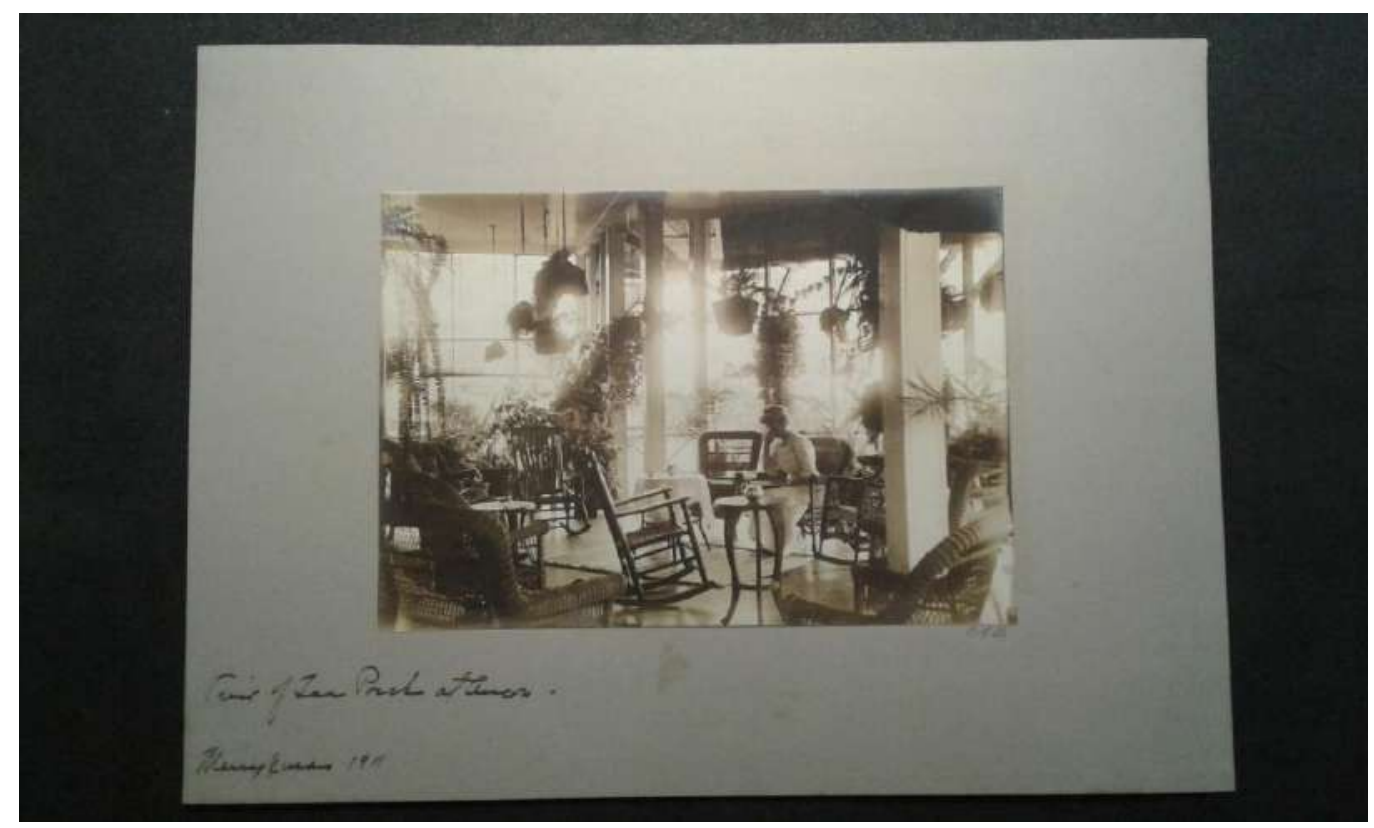

Fig. 4. Foto: «Visit of Jan. Porch, 1911». Image Archive, The Latin American Library, Tulane University

Lo que más conmueve a la señora Bayne es transitar por los espacios donde sucedieron las historias de piratas como Walter Raleigh, Henry Morgan o Francis Drake. Hace comentarios en los que se nota que ha leído historias sobre los reyes españoles, Colón, Pizarro, etc. Transmite sensaciones placenteras tales como sueño delicioso, mar del romance, libro de cuentos, camino tentador o iglesias llamativas. Aunque describe con detalle y cierta admiración el desarrollo de las obras e incluye numerosas fotos de la construcción del canal, muestra mayor interés por la historia. Edith siente que puede experimentar el pasado. Por ejemplo, cuando se dirigen a la isla Taboga comenta que «pudieron avistar a lo lejos la maravillosa Isla de las Perlas donde los buzos aún ejercen su peligroso oficio, como hacían los indios en tiempos de los primeros españoles para deleitar a su Rey con obsequios de estas relucientes gemas» (Bayne 22). Concibe un pasado romantizado y bucólico.

Por supuesto Edith visita la Torre de la Vieja de Panamá, comenta que «se encuentran en el lugar de la famosa batalla en la que el cruel bucanero Morgan peleó contra los nativos, en ese entonces la ciudad más rica del mundo y que allí se escondió Francis Drake por un año esperando confiscar los ricos tesoros de Perú». Entonces dice que «no queda nada para contar acerca de la historia de esta Ciudad de innumerables - 186 - CLAVES. REVISTA DE HISTORIA, VOL. 7, N.o 12 (ENERO-JUNIO 2021) $\quad$ ISSN 2393-6584 
riquezas, salvo una torre perteneciente a un antiguo Monasterio, último reducto de los desgraciados españoles. Nunca fue reconstruido» (Bayne 7).

En su álbum incluye una de las postales prototípicas de sublime vegetación y otra más impactante aún, en que la torre apenas sobresale de una selva de palmeras que parecieran a punto de tragársela sin dejar rastros. Lo mismo sucede con otra sugestiva imagen de un puente en el antiguo camino hacia la vieja Panamá (Fig. 5).

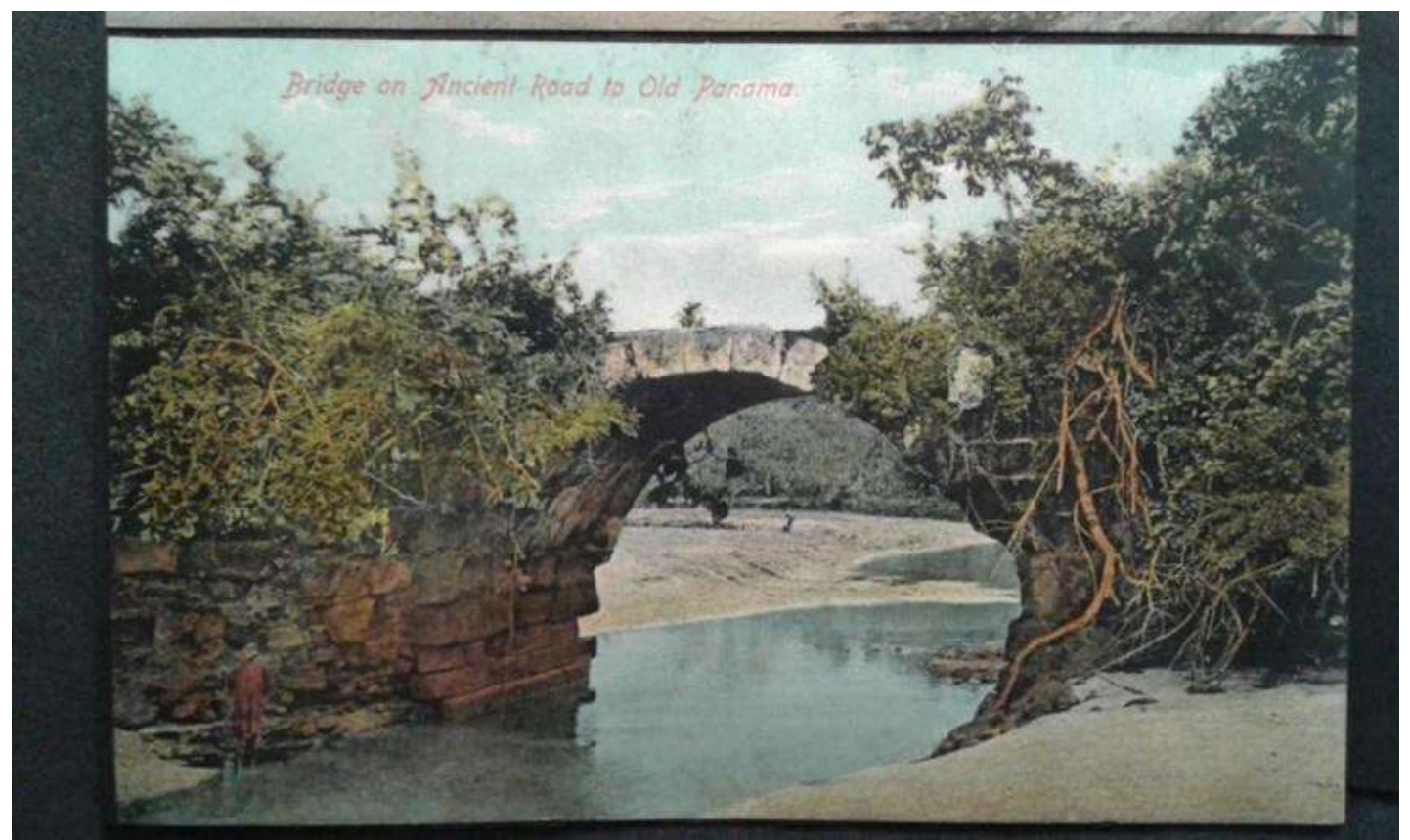

Fig. 5. Postal: «Bridge on Ancient Road to Old Panama». Image Archive, The Latin American Library, Tulane University.

Se ve un arco sobre el río cubierto por vegetación, destacándose las raíces que se extienden por las piedras de la construcción. La calzada que corre por arriba es apenas visible. Estas imágenes forman parte del imaginario que producen la atracción y sensación de estar experimentando el tiempo pasado que describe Edith.

En contraste con las ruinas, las iglesias, el fuerte, los ranchos, las riñas de gallos y las cabras pastando en el malecón, Edith agrega imágenes del canal y las construcciones norteamericanas. La foto de una calle mostrando el antes y el después refuerza las comparaciones (Fig. 6). Una mujer y una niña están paradas frente a una calle intransitable por el barro, unos barriles y tablones tirados hacen las veces de puentes para transitar entre el agua y las piedras. Al fondo se ven unos carros destartalados con caballos. El epígrafe aclara que es: «una calle de la ciudad de Colón como era antes que los Estados Unidos obtuviera el control del canal». La siguiente imagen, pegada en el álbum, muestra la calle, según aclara el texto al pie de la imagen, «reparada por la administración americana». En esa escena, un señor, de punta en blanco, camina por una 
vereda estrecha, pero regular que distingue la zona peatonal de la calle que ya no muestra el barro que antes dificultaba el tránsito y al fondo se ve otro carro que puede cruzar sin los problemas previos. La comparación ofrece una idea temporal y política de la diferencia.

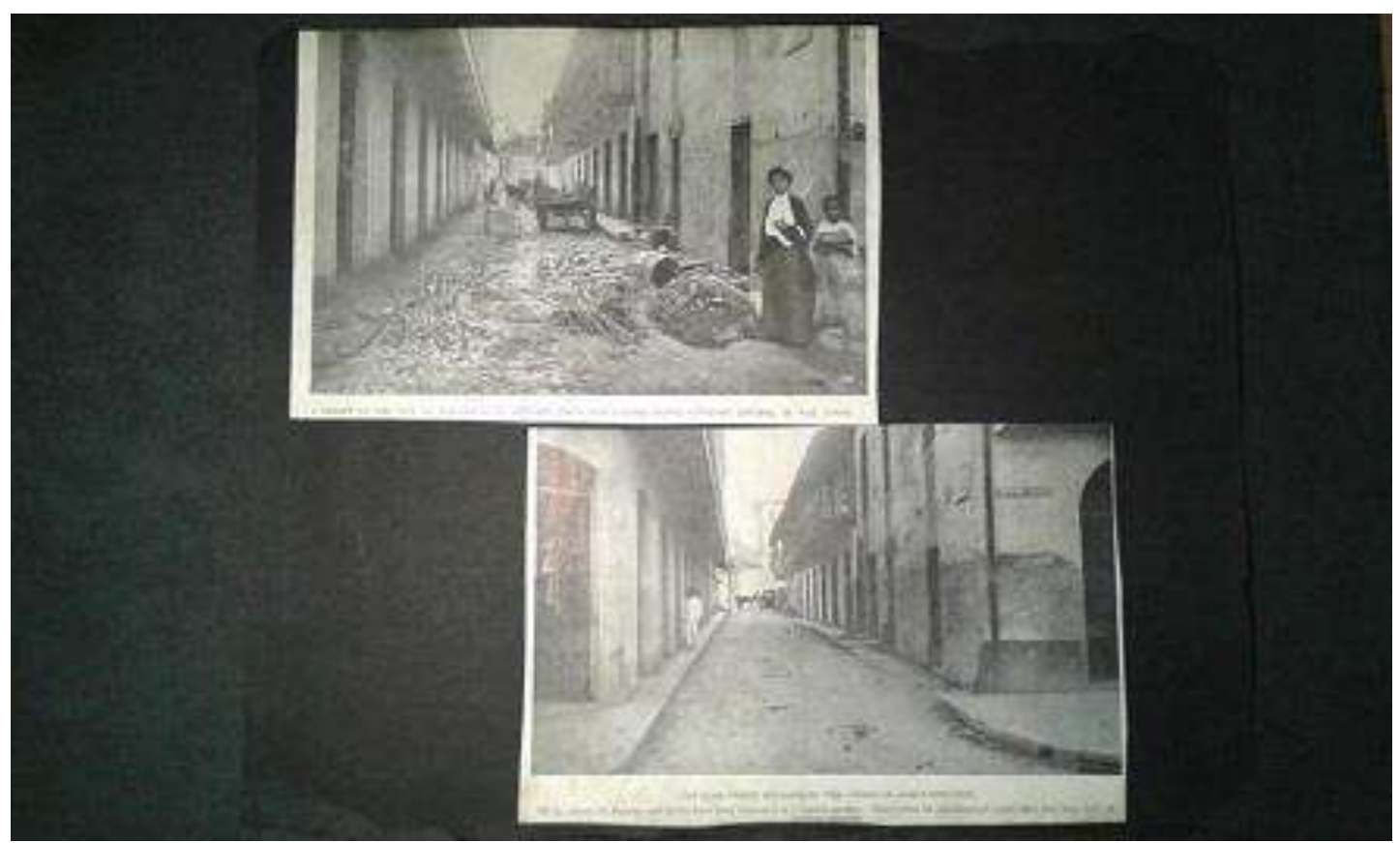

Fig. 6. Arriba: «A street in the city of Panama as it appeared when the United States obtained control of the canal.» Abajo: «The same street repaired by the American administration. All the streets of Panama and Colon have been renovated in a similar manner. Many miles of macadamized roads have also been built in outliving districts.» Image Archive, The Latin American Library, Tulane University.

$\mathrm{Al}$ volver de la excursión a Taboga, Edith cuenta que se detienen en las afueras de la vieja Panamá: «mirando a su alrededor en busca de fantasmas de los viejos guerreros españoles y los cientos que Morgan masacró», pero agrega que al continuar unos pocos kilómetros más adelante «pasamos del pasado al presente práctico, de las maravillas que la fuerza y la resistencia del hombre lograron a las maravillas creadas por su intelecto». Completa este relato describiendo las cañerías, los barcos y locomotoras a petróleo en vez de carbón para referirse al presente (Bayne 24-25).

La ciudad de Panamá no le parece muy interesante, lo único que destaca es que casi todos los negocios son chinos. Dice:

\footnotetext{
«me siento como si hubiera viajado en mi alfombra mágica a China cuyas costas están bañadas por el mismo océano. No hay dudas que los barcos llegan directo, ya que hay gran riqueza en hermosos bronces, marfiles y bordados que no vemos aquí, ni siquiera en los negocios chinos americanizados de Nueva York en San Valentín» (Bayne 9).
} 
Expresa su admiración al vincular su experiencia con historias fantásticas y pensar en los intercambios a través del Pacífico.

Al finalizar, y a modo de balance, Edith sostiene que le ha gustado ver la construcción del canal, pero que le resulta:

... agradable también pensar que mi sed de información nunca me tentará a hacerlo de nuevo. Me recosté en una silla de vapor y soñé con las cosas maravillosas que había visto, con la alegría de llegar a casa, hasta que avistamos a mi querida Nueva Orleans. El viaje terminó, dejándome con una idea del maravilloso Canal y muchos recuerdos agradables (Bayne 31).

Como sucedía con los relatos de viajes típicos de la época, esa reflexión revela el objetivo de conocimiento que tenía su viaje. En esa experiencia la vista y la observación tienen un lugar central. Bayne pudo ver la gran obra de ingeniería, aunque su preferencia se centró en la observación y experiencia del pasado. No hay en su relato interés por una historia más reciente o por explicaciones históricas, sino descripciones edulcoradas de los sucesos cercanos a la conquista. Hay que tener en cuenta que la región de Nueva Orleans fue parte del imperio hispano además del francés, por lo que puede haber relatos que le son conocidos por su propia formación.

El relato de Edith muestra una experiencia personal e individual, irrepetible ya que presenta su visión subjetiva. Su biografía muestra una mujer que, si bien cuidó los hijos de su hermana y estuvo casada con un hombre acomodado del sur de Estados Unidos, no se quedó en su casa ocupándose de la cocina y las tareas domésticas, sino que estudió, trabajó como voluntaria, se dedicó a la asistencia social, viajó y escribió relatos con sus impresiones. De todos modos, es un caso testigo de una práctica que se estaba generalizando: viajes turísticos, por el placer de diversión y descanso junto al afán de conocimiento de una región reconocida por su atractivo natural, su pasado colonial y por el desarrollo de una obra paradigmática de modernidad.

Tanto en las postales de la Torre de Panamá la Vieja como en el relato de Bayne hay una relación directa entre viaje, visualismo y distancia temporal. Al trasladarse de un país a otro se produce no solo una distancia física, sino también temporal que se manifiesta en forma de imágenes gráficas. Este entramado también se puede observar en el caso de Cuba que se analiza a continuación.

\section{Cuba: el paraíso tropical de las Indias Occidentales}


Las imágenes de folletos, postales y fotografías entre finales del siglo XIX y principios del Xx resaltan las representaciones de Cuba como un paraíso tropical. La representación de América Latina como una naturaleza disponible ha sido un tópico bastante recurrente y estudiado. 4 Pero ha sido menos analizada en su vínculo con la temporalidad. La naturaleza era una forma de representar el pasado ya que la modernidad se mostraba con imágenes de lo urbano, la industria, el ferrocarril, entre otros aspectos. La tapa de un folleto denominado Cuba and the Cuba Railroad muestra un camino secundado por dos filas de palmeras representando un arquetipo tropical (Fig. 7). Se ve un hombre a caballo sin la menor presencia de algún ferrocarril al que debería aludir el título. Al pie del folleto hay un breve texto señalando que hay una vía, pero es necesario incluirlo de manera textual porque es difícil percibirlo. El folleto muestra una idea de temporalidad en la que la naturaleza se expone como un pasado que está siendo dejado de lado ante el avance de la modernidad que supone llegará pronto.
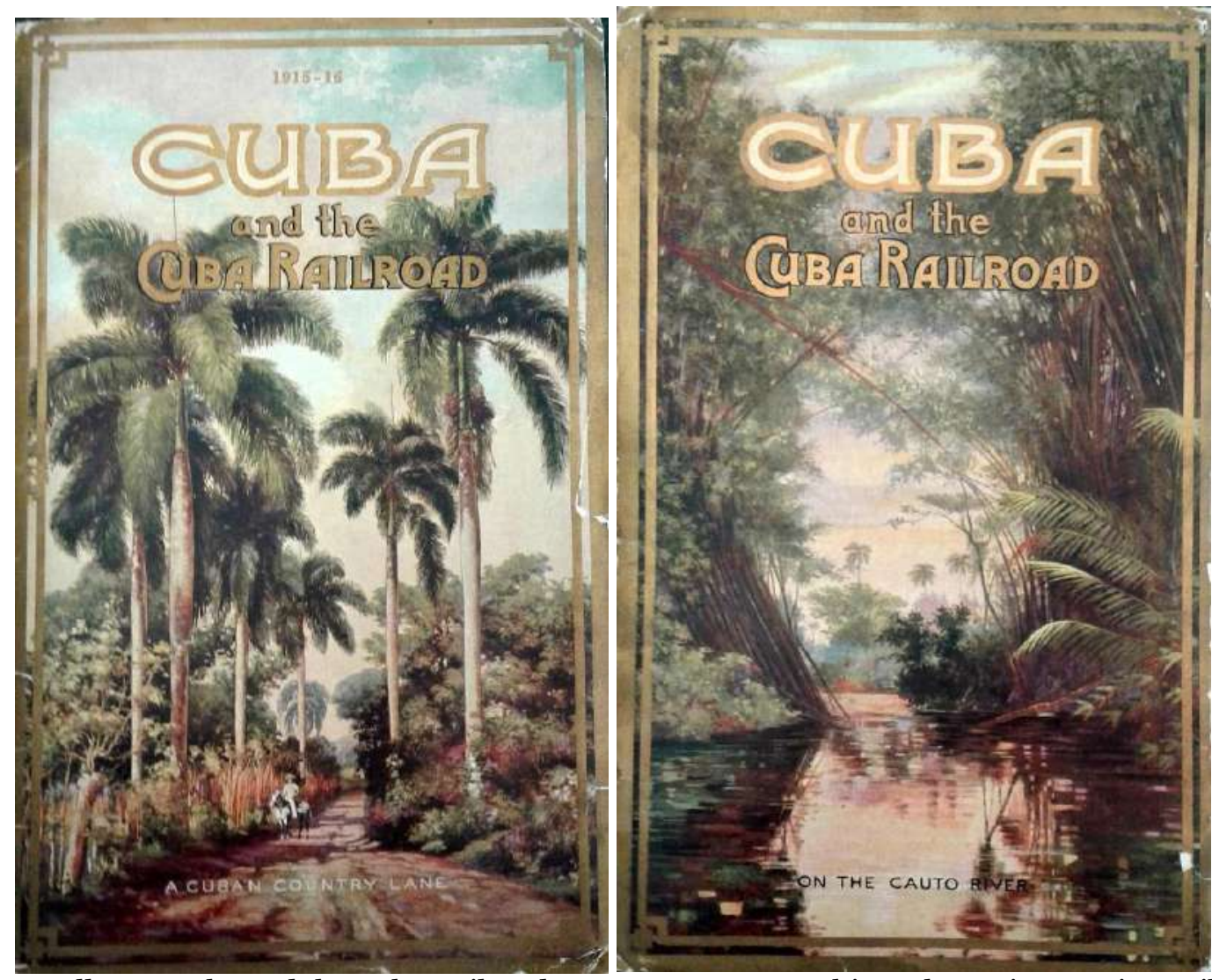

Fig. 7. Folleto: «Cuba and the Cuba Railroad», C. 1916. Image Archive, The Latin American Library, Tulane University.

\footnotetext{
4 Solo para mencionar algunos véanse de Certeau, Michel La escritura de la historia (Ciudad de México, Universidad Iberoamericana, 2006 [1975]). Pimentel, Juan Testigos del mundo. Ciencia, literatura y viajes en la Ilustración (Madrid, Marcial Pons, 2003). Penhos Marta, Ver, conocer, dominar. Imágenes de Sudamérica a fines del siglo XVIII (Buenos Aires, Siglo Veintiuno Editores, 2005); Yujnovsky, Inés (coord.) Historias latentes. Episodios de la fotografía en América Latina (Buenos Aires, Ampersand, en prensa).
} 
Romance, aventura y diversión fueron estereotipos recurrentes para referirse a Cuba. Son palabras que aluden a un tiempo diferente del cotidiano. Una época de romance es breve, de gran enamoramiento, quizás el inicio de una relación, de un amor especial. Supone un tiempo efímero, que puede estar ligado a las vacaciones y a una diversión pasajera. La aventura alude a un momento especial, propio de un viaje, de una expedición o de un recorrido a través de lo desconocido durante un período en general acotado, que no dura por siempre.

Ese tipo de temporalidad breve y especial es el que aparece en un díptico en el que una joven esbelta, delicada, con un vestido rosado y una sombrilla que ha dejado caer, disfruta de la brisa bajo una rama inclinada de la que brotan pequeñas flores (Fig. 8). Está rodeada de algunas mariposas amarillas que combinan con el cabello corto de la mujer. Este dibujo forma parte de la tapa de una lista de pasajeros de la línea de barcos a vapor Cunard, a principios de la década de 1920, que les desea felices pascuas a sus asistentes. En inglés dice joyful easter, de modo que tanto texto como imagen aluden al otoño y a la resurrección que se rememora en la pascua. Es un tiempo de reflexión, de esperanza y alegría. Pero el texto juega además con el nombre de la línea de barcos escrita al pie de la imagen: Easter Cruise to Havana. El título señala tanto la idea del punto cardinal como de la pascua. Los colores pálidos en rosa y amarillo, la delicadeza del trazo a lápiz, así

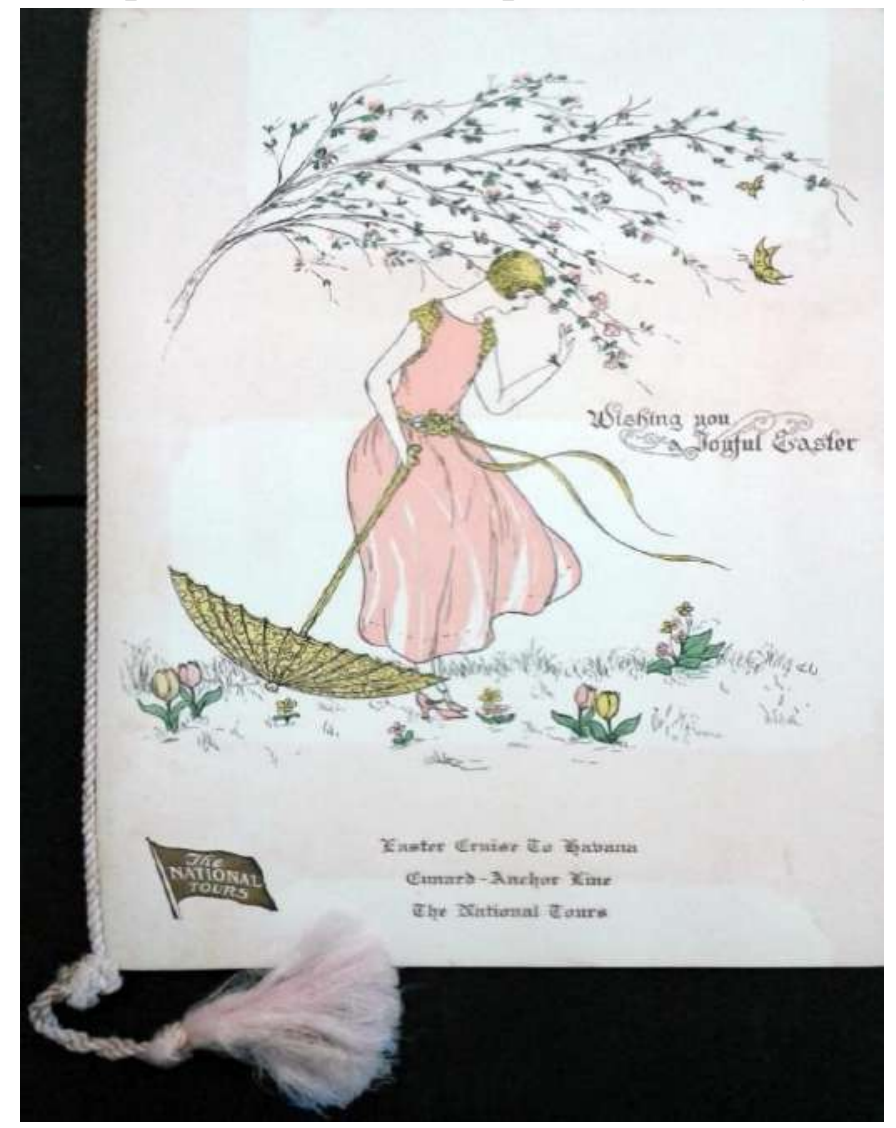
como un pompón atado con una cinta alrededor de la tarjeta, doblada al medio, transmiten un aire de seducción y erotismo. Los dedos de una de las manos de la joven apenas tocan una hoja, casi como un beso. La borla de algodón parece parte de un juego sensual para quien utiliza estos objetos que la compañía del barco regala a sus pasajeros y que ellos pueden atesorar como recuerdos de colección. Es una bella imagen que apela a un breve tiempo de seducción como incentivo para tomar el barco y realizar el viaje a Cuba. 
Una pequeña tarjeta, que se extrae de un sobre semitransparente, invita a visitar Cuba como tierra de intensa diversión y romance. Un patio interior de estilo colonial, algunas palmeras, las estrellas y la luna forman el marco de una cena al aire libre, en el que se ven parejas sentadas, conversando y bebiendo. En una de las mesas hay un hombre con dos mujeres y el centro de la imagen lo ocupa un rayo lumínico que se posa sobre dos bailarines en acción sensual. Otra postal, ya de la década de 1950, presenta el Bar de Sloppy Joe que se muestra atestado de gente conversando, bebiendo, parados, sentados en las mesas o parados junto a la barra servida por algunos barmen (Fig. 9). La mayoría son hombres. En el reverso de la postal un amigo le escribe unas líneas a un compañero en Brooklyn diciéndole: Man, this is living. Expresa con claridad la alegría sentida, una emoción del buen vivir durante unas vacaciones en Cuba. Diversión sí, pero propia de un período corto de tiempo, posible para unas pocas semanas. Estos bellos y delicados objetos de colección, atesoramiento e intercambio seducían, impulsaban a emprender esas deseadas vacaciones, viajes de aventuras y placer, afirmaban también esos lapsos de vida intensa, bebida y cuerpos en movimiento.

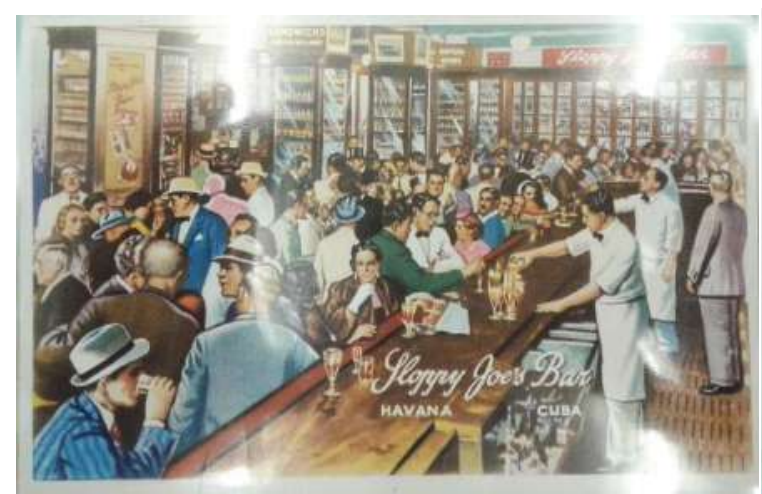

Fig. 8. Lista de pasajeros: "Easter Cruise to Havana. Cunard-Anchor Line. The National Tours", C. 1923. Image Archive, The Latin American Library, Tulane University.

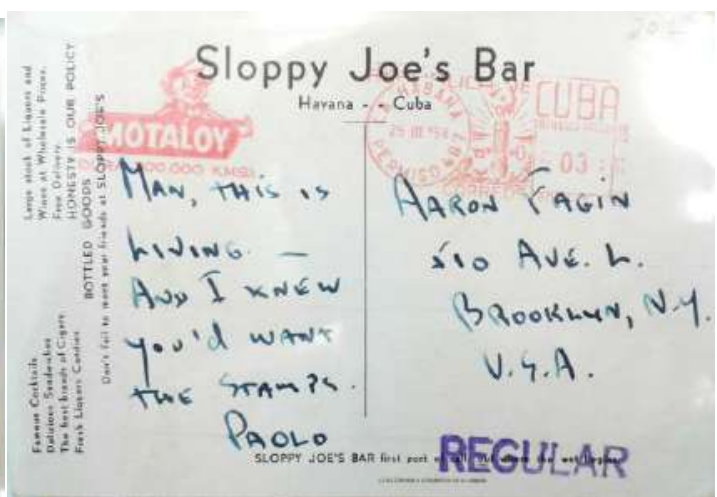

Fig. 9. Postal: «Happy Joe’s Bar, Havana», Fecha del sello postal 1956. Image Archive, The Latin American Library, Tulane University

\section{El Castillo del Morro}

El Castillo de los Tres Reyes Magos del Morro, conocido como El Morro o el Castillo del Morro fue el punto de interés turístico principal, la visita obligada para todo viajero o viajera que se dirigiera a La Habana. Las imágenes de la antigua muralla al borde del mar, de un celeste translúcido, se repiten en una y otra escena de Cuba. El faro se distingue en la punta de la península; cual una columna se yergue resistiendo el embate de los años. En el límite, entre la tierra y el mar, brinda la bienvenida ante la primera impresión que tenían los viajeros al llegar a Cuba. Es la guía, la seguridad y el punto de 
referencia para el navegante. Representa además la defensa de los españoles que desafiaron a los ingleses en 1762 generando un efecto similar a las ruinas de la torre de Panamá. Un faro que ilumina en circunstancias adversas, tanto un pasado español como la amenaza inglesa. A diferencia de otras imágenes del siglo XIX en las que se destaca el mar revuelto, sublime y de tormentas, las imágenes de El Morro muestran un mar calmo, sin oleaje, con un cielo despejado y el brillo del sol sobre veleros y barcos que navegan con tranquilidad. Los folletos repiten frases como «el paraíso tropical de las indias occidentales» o «Habana, Cuba, la ciudad del charme»o «la tierra más encantadora que ojos humanos hayan visto jamás». Palabras que, como la imagen del morro, manifiestan el esplendor natural como algo que pareciera eterno.

Los folletos ponen de relieve la expansión de los intercambios en el Caribe, entre Nueva Orleans, Cuba, Panamá, pero también incluyendo Nueva York y, hacia Sudamérica, Río de Janeiro, Montevideo, Buenos Aires y Valparaíso, entre otras ciudades americanas. Insisten en que los barcos a vapor ofrecen tiempos de navegación «tan regulares como el sol», parten puntuales y llegan a destino en cuestión de horas. En vez de promocionar un viaje de dos días sostienen que se completa en cuarenta horas, además de señalar la facilidad para desembarcar y el ingreso directo a los hoteles cercanos que reducen el tiempo de traslado.

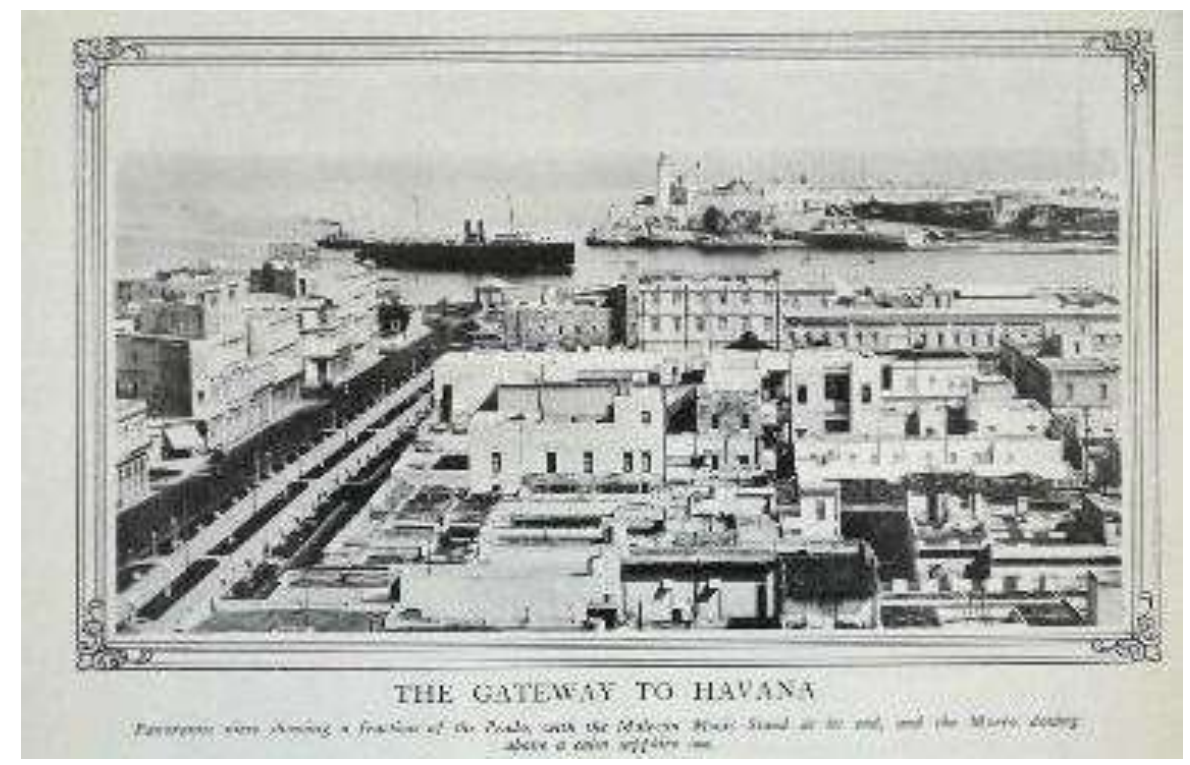

Fig. 10.

Interior del Folleto: «Cuba the loveliest land that human eyes have ever seen». C. 1920. Image Archive, The Latin American Library, Tulane University.

Un folleto, elaborado por la Comisión Oficial de Turismo de Cuba en 1920, muestra una vista más lejana de La Habana con el Castillo del Morro en el fondo (Fig. 10). En el centro de la imagen se ve un barco a vapor ingresando por el canal hacia el muelle mientras que el primer plano de la foto muestra la ciudad, en la que conviven edificios 
antiguos con la moderna y ancha avenida Prado, preparada para el ir y venir de autos, con faroles para iluminar el recorrido durante la noche. La configuración formal de la imagen pone de manifiesto las representaciones de la temporalidad: las ideas del presente están en el primer plano, la ciudad renovada se ve primero. Más atrás hay un barco a vapor entrando al puerto que representa la modernidad. Aunque está en un segundo plano se ubica casi en el centro de la imagen y el movimiento representa una acción bisagra entre el pasado, el presente y el futuro. En tercer plano y más atrás se encuentra El Morro, una imagen que alude al pasado colonial hispano, una arquitectura que recuerda los tiempos que ya no volverán. En los textos del folleto ese pasado es considerado de manera despectiva: «las calles estrechas y tortuosas de la ciudad vieja se parecen a las de los pueblos españoles primitivos como Sevilla, Granada o Toledo» Mencionan que esas calles tipifican «la vieja España con tanta fidelidad que en varias ocasiones han sido utilizadas en escenas de filmación por compañías cinematográficas».5 Se presenta el pasado de manera binaria en contraste con el advenimiento de la modernidad.

Una de las tiendas más importantes de Cuba denominada El Encanto, ofrecía, hacia 1933, un folleto para hacer la visita más interesante y «refrescar en la memoria» algunos hechos históricos con una breve historia de Cuba (Fig. 11). Señalaban que «a menudo es difícil visualizar los escenarios del pasado romántico al confrontar el esplendor y el logro del presente» (Golden Hour 1). Por esa razón muestran una yuxtaposición de viejas imágenes con fotografías de similares entornos en la actualidad. En una doble página, hay un dibujo que representa el descubrimiento de América, la llegada de Cristóbal Colón en una playa con palmeras que contrasta con la foto de la página contigua: una vista panorámica en la que se destaca un avión surcando los aires de la península de La Habana. Así se repiten la mayoría de las páginas del folleto. El título es Golden Hour at Spanish Main para aludir a la hora mágica o dorada, cuando el sol está cerca del horizonte tanto al amanecer como al atardecer y en la que los colores se tornan rosados, azules y dorados gracias a la iluminación suave y difusa. Spanish Main se asocia a la llegada de los españoles a la costa del Caribe, a la búsqueda de tesoros y a la piratería. Es un título que, en pocas palabras, resalta ideas románticas del tiempo, una hora de gran encanto que se desvanece pronto, efímera, pero llena de tesoros. La publicidad de $E l$ Encanto afirma que «La Habana tiene el alma del pasado entremezclado con el espíritu

\footnotetext{
${ }^{5}$ CUBA. The Loveliest Land that Human Eyes Have Ever Seen. (Cuba, Cuban Official Tourist Commission, 1920), p. 4
} 
del presente de la forma más romántica» (Golden Hour 1). A las comodidades del presente moderno, encarnado en los barcos a vapor, los hoteles, la gran avenida con faroles eléctricos se agrega un marco de aventura y naturaleza, perduración del pasado, que ofrecen un tiempo breve e intenso ideal para un viaje turístico.
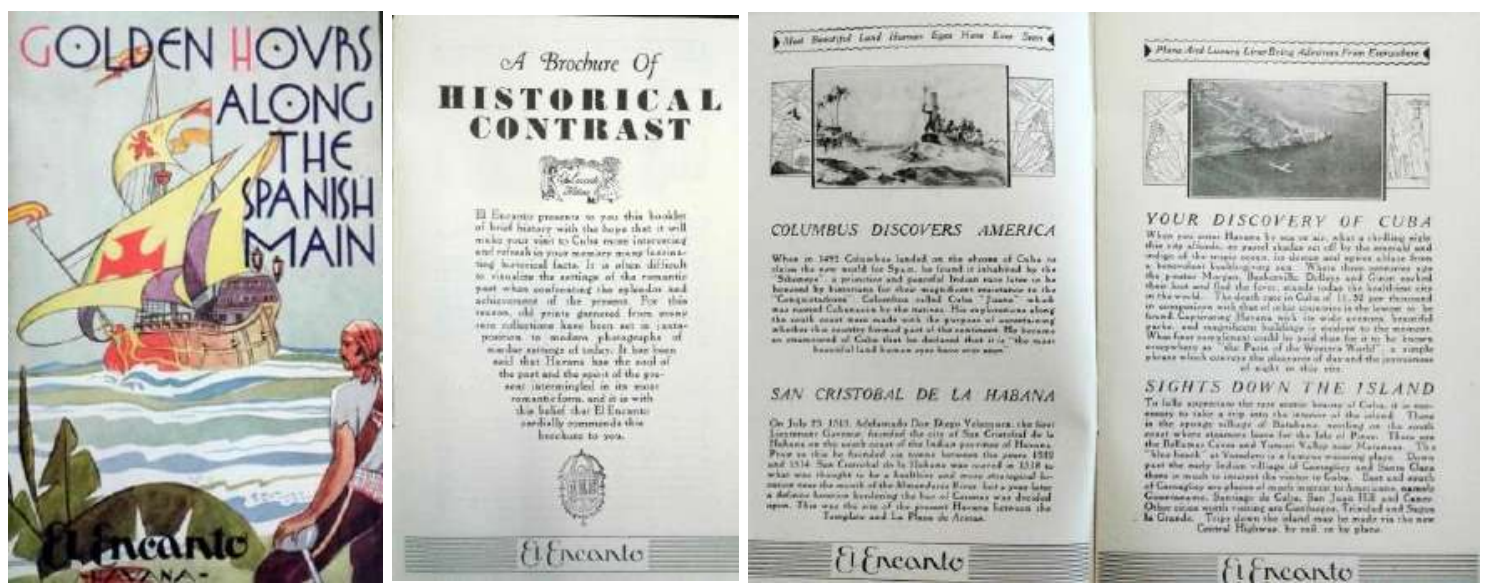

Fig. 11. Folleto de Tiendas El Encanto: «Golden Hours along the Spanish Main». C. 1933. Image Archive, The Latin American Library, Tulane University

\section{El Capitolio}

En la actualidad la información sobre uno de los edificios representativos de La Habana sostiene que:

«El Capitolio Nacional de Cuba es una de las edificaciones más emblemáticas de la ciudad de La Habana. Esta majestuosa edificación es similar al Capitolio de Washington D. C, pero un metro más alto, un metro más largo y mucho más rico en detalle. Las obras de su construcción fueron iniciadas por el dictador cubano Gerardo Machado en el año 1926 con respaldo norteamericano» (Visitar Cuba).

La comparación con el edificio parlamentario norteamericano tiene un correlato visual en las imágenes de esos años.

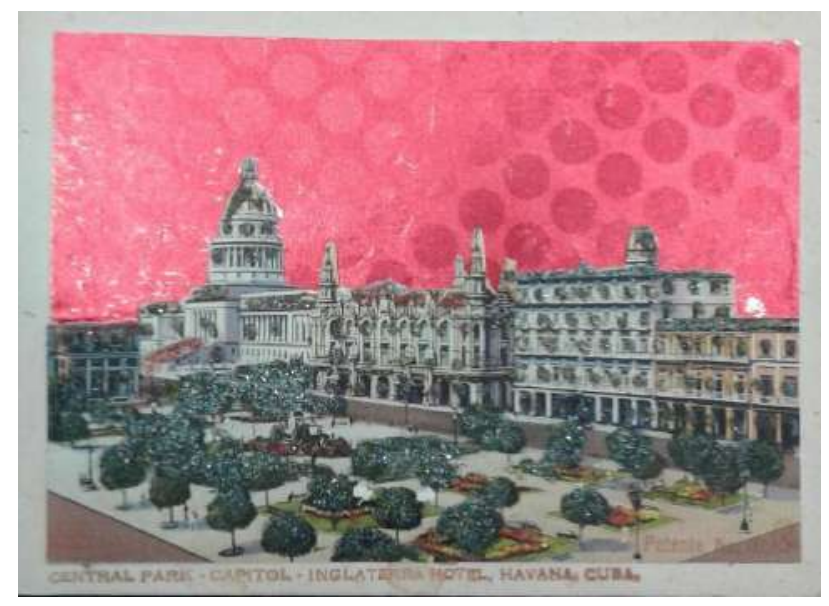

Fig. 12. Postal Popup: Central Park - Capitol - Inglaterra Hotel, Havana, Cuba. C. 1930. Image Archive, The Latin American Library, Tulane University. 
Una pequeña postal de estilo pop up, de la década de 1930, muestra al capitolio para representar la imagen de la nueva democracia impulsada por Estados Unidos, algunos brillos pegados sobre la cúpula refuerzan su importancia y elegancia (Fig. 12). El hotel Inglaterra subraya el pasado y presente inglés. La referencia a La Habana, al pie de la postal señala el lugar: una plaza central en la que los árboles brillan del mismo modo que la cúpula, junto a los faroles eléctricos. Los árboles y la plaza son subrayados por la tridimensionalidad de la solapa que se levanta apenas un centímetro, pero aporta al interés por estar allí adentro, en una urbe moderna en su materialidad y antigua en su pasado. Esta pequeña pieza gráfica muestra, tanto por su contenido como por su forma, la superposición de temporalidad moderna-antigua que aparecía en el folleto de $E l$ Encanto y en otras publicidades de la época. Este contraste de la vieja y moderna Habana continúa presente en un folleto realizado por el gobierno de Cuba a través de la Oficina Cubana de Turismo, en 1947 (Fig. 13). Es un tríptico que en su tapa lleva escrito Cuba la tierra de la fascinación. Se destacan la imagen del capitolio, de los faroles y en el epígrafe aclara que esa es la Habana Moderna. En la parte posterior del folleto se ve un viejo patio enmarcado por la exuberante naturaleza en la que caminan de espalda dos bellas mujeres. La arquitectura de la democracia norteamericana resalta el presente mientras que la del pasado colonial, la naturaleza y lo femenino representan a la Vieja Habana. Continúan entrelazándose los dos tiempos, uno político, masculino, moderno y actual frente al femenino sensual, pasado y exuberante.

Las publicidades mencionan el impacto de extraordinario atractivo que produce observar aspectos ajenos a la propia realidad del viajero. Para muchos, dicen:

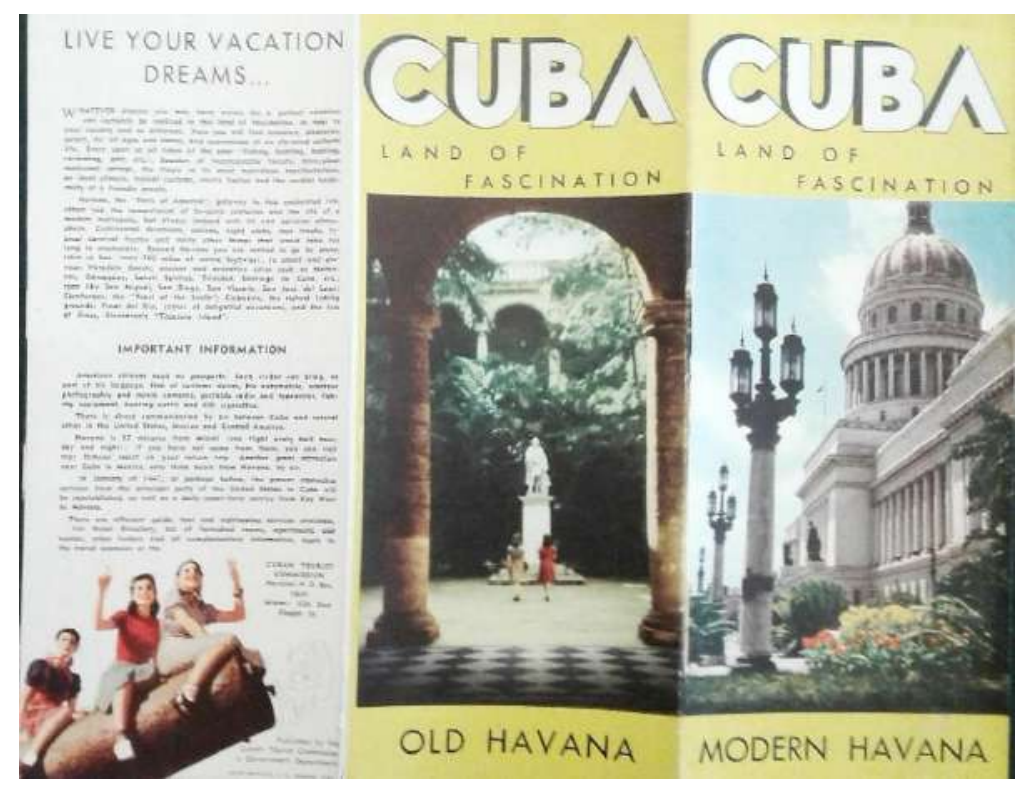

Fig. 13. Folleto: «Cuba Land of Fascination", c. 1947. Image Archive, The Latin American Library, Tulane University. 
«Cuba ha sido solo escenas de novelas románticas, el recuerdo de una lección de geografía, o un país lejano al que pocos llegan, pero aquellos que en las nuevas condiciones pueden viajar siempre van a recordar Cuba y van a poder contar reminiscencias fascinantes, manteniendo fascinados a los oyentes en casa» (Cuba Land of Fascination).

Las publicidades resumen así una experiencia positiva por el impacto del encuentro con el otro, porque produce recuerdos que serán recordados y porque a su vez podrán ejercer fascinación sobre quienes escuchen los relatos al regreso del viaje.

\section{Consideraciones finales}

Los dos casos seleccionados muestran formas de promoción turística estandarizadas y similares como la atracción por la historia, la posibilidad de poder experimentar un pasado romántico y de revivir aventuras. Se trata de dos espacios que atravesaron circunstancias parecidas como la sujeción a la monarquía hispanoamericana, la fuerte impronta de la religión católica y la presencia de otras potencias mundiales. Desde visiones externas, como las norteamericanas, se relataron historias para el conjunto de esta área que incluían la llegada de los primeros conquistadores, el establecimiento de los encomenderos, el comercio y la piratería. Sin embargo, en cada caso se adaptaron los discursos generales a las circunstancias locales.

Tanto en Panamá como en Cuba la propaganda promocionaba un sitio central, construido en el período colonial, que se convertía en una referencia turística, fotografiada y representada en diversas ilustraciones. En Panamá fue el primer emplazamiento de la ciudad, abandonado en 1671, y que a principios del siglo XX se encontraba cerca del centro, pero que requería de un desplazamiento para ir a recorrerlo. En Cuba, el Morro era la primera referencia que se veía desde el barco. En ambos casos se las propone como ruinas y se refieren a construcciones del período colonial.

Al afirmar que el atractivo de países como Cuba y Panamá radicaba en la presencia de resabios hispanos, románticos y de aventuras que se manifestaban en un paraíso tropical natural se ofrecía la posibilidad de vivir una experiencia que combinara las comodidades de la modernidad con el placer del pasado natural y sensual. De esta manera, los viajeros y viajeras podían apreciar la combinación de los distintos estratos temporales. La seducción de la historia, la posibilidad de percibir y experimentar sensaciones del pasado fueron un gran atractivo de este tipo de viajes. Estas ideas de temporalidad forman parte de relaciones que buscan poner lo moderno en la jerarquía 
superior y lo viejo y natural en un lugar de subordinación. Generan la distancia espacio temporal que propone la negación de la coetaneidad propuesta por Johannes Fabian.

En el caso de Panamá se enfatizó a través de la imaginería de ruinas, rodeadas por la naturaleza. La visualización de la moderna construcción del Canal quedó, en cierta medida, separada del pasado colonial. En Cuba aparece más el contraste entre pasado y presente. La modernidad y la construcción de lo nuevo se genera a partir de la perduración de ciertos discursos sobre el pasado que muestra la decadencia, con pocos efectos sobre el presente, pero que al mismo tiempo puede ser aprovechado para generar sentimientos de aventura, romance y diversión. En ambos casos el mar produce fascinación, no solo el entorno natural, los colores al atardecer, sino por la evocación al pasado de piratas y bucaneros.

En consonancia con esa perspectiva aquí se analizaron las fotografías, postales y folletos que circularon en la región. Las mujeres estaban representadas en las imágenes, a veces asimiladas al pasado natural, pero también estuvieron presentes y activas viajando, conociendo, coleccionando y relatando sus experiencias, deseos e intereses. La seducción y la aventura podían estar destinada a los hombres, pero también las mujeres produjeron y consumieron diversión, erotismo y atracción por la historia y la modernidad. El consumo no es una actitud pasiva de recepción también implica apropiación, selección y en este caso incluso la decisión, el gasto y el impulso de viajar, trasladarse, conocer y enfrentar preconcepciones con las experiencias propias y de encuentro con esta región. Tampoco las imágenes se han analizado como reproductoras de discursos o visiones previas que se muestran en las fotos, postales y folletos, sino que forman parte de un entramado perceptivo, discursivo y de conocimiento que ayudaron a construir y difundir imaginarios y que generaron efectos e impactaron en la comprensión del pasado y del presente.

\section{Obras citadas}

\subsection{Archivos}

The Latin American Library at Tulane, Nueva Orleans, Estados Unidos. Image Archive. Photograph Collections.

\subsection{Fuentes}

Bayne Denègre, Edith. My trip to Panama. (New Orleans, 1911). Manuscripts/Collection 58. Image Archive, The Latin American Library, Tulane University.

CUBA. The Loveliest Land that Human Eyes Have Ever Seen. (Cuba, Cuban Official Tourist Commission, 1920). 
Cuba Land of Fascination, (Cuba, Cuban Tourist Commission, 1947).

Golden Hour at Spanish Main. (Cuba, Tiendas El Encanto, C. 1933).

Jambalaya [yearbook] Tulane University, vol 9, 1904.

Simmel, Georg. «Two Essays», The Hudson Review, Vol. 11, No. 3 (Autumn, 1958), pp. 371-385 [1911].

Visitar Cuba «Capitolio Nacional de Cuba» https://www.visitarcuba.org/capitolionacional-de-cuba. Consulta 20 de marzo de 2021.

\subsection{Bibliografía}

Arroyo Duarte, Silvia. «La cartografía histórica, los grabados, las fotografías y descripciones como ayuda para estudiar la historia del sitio arqueológico de Panamá viejo después de su destrucción», Iglesias Rodríguez, Juan J. et alii (eds.): Comercio y cultura en la edad moderna. Universidad de Sevilla, 2015: 2941-2961.

Baroni, Mirta Linero. «El sitio arqueológico Panamá Viejo. Integración urbana de un ícono en ruinas», Centroamérica. Identidad y patrimonio cultural | Actas del I Simposio Internacional, Sevilla: 80-87.

de Certeau, Michel. La escritura de la historia (Ciudad de México, Universidad Iberoamericana, 2006 [1975]).

Cifuentes, María Ángela. «Postales, viaje y turismo: La experiencia de una viajera ecuatoriana a inicios del siglo XX», Historia Contemporánea, 63: 585-630.

Cocks, Catherine. Tropical Whites: The Rise of the Tourist South in the Americas (Filadelfia, University of Pennsylvania Press, 2013).

Downes, Stephanie; Sally Holloway, Sarah Randles, Feeling Things: Objects and Emotions Through History (Oxford, Oxford University Press, 2018).

Fabian, Johannes. El tiempo y el otro. Cómo construye su objeto la antropología (Bogotá, Ediciones Uniandes-Popayán, Universidad de Cauca, 2019).

Gordillo, Gastón. Rubble. The Afterlife of Destruction (Durkham, Duke University Press, 2014).

Graves-Brown, Paul; Rodney Harrison; Angela Piccini, The Oxford Handbook of the Archaeology of the Contemporary World (Oxford, Oxford University Press, 2013).

Lasso, Marixa (a). «From Citizens to Natives: Tropical Politics of Depopulation at the Panama Canal Zone», Environmental History 21 (Abril 2016): 240-249.

- (b). Erased: The Untold Story of the Panama Canal (Cambridge MA, Harvard University Press, 2019).

Makarius, Michel. Ruines (Turín, Flammarion, 2004).

Masotta, Carlos. «Representación e iconografía de dos tipos nacionales. El caso de las postales etnográficas en Argentina 1900-1930», Arte y antropología en la Argentina (Buenos Aires, Fundación Telefónica y Fundación Espigas, 2005): 65114 .

Milanesio, Natalia. Cuando los trabajadores salieron de compras, nuevos consumidores, publicidad y cambio cultural durante el primer peronismo. (Buenos Aires, Siglo XXI, 2014). 
Miseres, Vanesa. «Materiales de viaje: La función de los objetos en las fotografías, ensayos y diario personal de Alice Dixon Le Plongeon en Yucatán». Latin American Research Review, 56 (1), (2021): 126-141. doi: http://doi.org/10.25222/larr.866

- «Lectoras, autoras y consumidoras: Los usos femeninos del álbum en Latinoamérica», Telar 23 (enero-julio/2019): 25-48.

Moxey, Keith. Visual Time. The Image in History (Durham, Duke University Press, 2013).

Neagle, Michael E. «"That Magnificent Land of Sunshine, Health, and Wealth”: How U.S. Entrepreneurs Sold Cuba's Isle of Pines», The Journal of the Gilded Age and Progressive Era, Vol. 11, N. 4 (Octubre 2012): 575-611.

Penhos, Marta Ver, conocer, dominar. Imágenes de Sudamérica a fines del siglo XVIII (Buenos Aires, Siglo Veintiuno Editores, 2005).

Pimentel, Juan Testigos del mundo. Ciencia, literatura y viajes en la Ilustración (Madrid, Marcial Pons, 2003).

Ramos Kneisley, Carol. «Postcards from Cuba», Material Culture, Vol. 38, N. 2 (Otoño 2006): 53-61.

Reese, Carol McMichael y Thomas F. Reese, El Canal de Panamá y su legado arquitecto nico (1905-1920) (Panamá, Fundación Ciudad del Saber, 2013).

Rose, Gillian and Divya P. Tolia-Kelly, Visuality/Materiality: Images, Objects and Practices (Abingdon y Nueva York, Routledge, 2012).

Skwiot, Christine. The purposes of paradise: U.S. tourism and empire in Cuba and Hawai i. (Filadelfia, University of Pennsylvania Press, 2010).

Troncoso, Claudia Alejandra. «El desplazamiento turístico a través de propuestas de recorridos e itinerarios. La ciudad de Salta (Argentina) y la consolidación de los paseos por su centro histórico», Claves. Revista de Historia, 6 (10), (2020): 95119 .

Yujnovsky, Inés (coord.). Historias latentes. Episodios de la fotografía en América Latina, (Buenos Aires, Ampersand, en prensa). 